\title{
Occurrence of Soil Tumors Northeast of the Guánica Lagoon, Lajas Valley, P.R. ${ }^{1}$
}

\author{
G. Acevedo, M. A. Lugo-López, and J. Ortiz-Vélez ${ }^{2}$
}

\section{INTRODUCTION}

A rather interesting situation was observed northeast of the Guánica Lagoon during the course of a recent soil survey of Lajas Valley. The soil, derived from old alluvium, is compact, heavy, and poorly drained. Numerous mounds or tumors oozing sticky clay suspensions occur throughout the area. These tumors present an unusual phenomenon, as they have not been found anywhere else in the Valley or in Puerto Rico. Roberts, in his extensive Islandwide soil survey, observed these tumors and mentioned them briefly in his report $(4)^{3}$. Their observation during the recent survey aroused interest as to their origin, distribution, and physical and chemical properties.

This paper reports the research findings concerning these tumors in a part of the Lajas Valley where an irrigation and drainage development project is under construction.

\section{MATERIALS AND METHODS}

Detailed field observations were made of the whole area northeast of the Guánica Lagoon in an effort to determine the distribution of the oozing soil mounds. Information was gathered as to the agricultural practices in the areas adjacent to the tumors, particularly the irrigation schedules. Notes were taken on differences in vegetation in the tumors and adjacent areas. Data were taken from piezometer batteries installed in the area and in the vicinity in connection with a more extensive investigation of watertable depths and movement in the Lajas Valley.

Three sites were selected for study and, at each, soil samples were taken from tumors that were not oozing at the time, at the following depths: $0-8$, 8-24, 24-48, and 48-72 inches. Samples were taken also at the same depths from the soil next to each selected tumor, at a distance of approximately 6 feet from the edge of the tumor. The samples were air-dried and passed through a 2-mm. sieve.

1 Joint contribution from the Department of Soils, Gurabo Substation, and Lajas Substation.

2 Research Assistant in Soils, Soil Scientist in Charge of the Gurabo Substation, and Research Assistant in Agronomy, respectively, Agricultural Experiment Station, Río Piedras, Gurabo, and Lajas, P.R.

3 Italic numbers in parentheses refer to Literature Cited, p. 114-5. 
A saturated soil paste was prepared using a $250-\mathrm{gm}$. sample following procedure 2 of the U. S. Salinity Laboratory (3). It was then transferred to a Richards' funnel and vacuum-extracted as outlined in procedure $3 \mathrm{a}$ $(8)$. The saturation percentage or the moisture content of the saturated soil paste, expressed on an air-dry soil-weight basis, was recorded for each sample. The following determinations were made on each of the saturation extracts: Conductivity value expressed in millimhos per centimeter, and calcium and magnesium expressed in milliequivalents per liter of $\mathrm{Ca}+$ Mg. Procedures 4b and 7, respectively, as recommended by the U. S. Salinity Laboratory (3), were used for these determinations.

The soluble sodium, expressed in milliequivalents per liter, was calculated by subtracting soluble $\mathrm{Ca}+\mathrm{Mg}$ from the total soluble bases. The total soluble bases were calculated by multiplying the conductivity value by 10, as recommended on page 157 of Agricultural Handbook 60 of the U. S. Salinity Laboratory (3). Total exchange capacity was determined by the ammonium acetate method. Exchangeable $\mathrm{Ca}+\mathrm{Mg}$, and $\mathrm{K}$ and $\mathrm{Na}$ were determined by the methods developed by Peech ( 5$)$. Organic matter was determined by the chromic acid titration method and nitrogen by the standard Kjeldahl technique. Mechanical analyses were performed by the approved pipette method. Water retentions at $\mathrm{pF}$ 's 2.7 and 4.2 were determined by subjecting saturated soil samples to tensions of $1 / 2$ and 15 atmospheres, respectively, in pressure chambers and special pressure plates.

\section{RESULTS AND DISCUSSION}

\section{ORIGIN AND DISTRIBUTION}

A survey of the area surrounding the Guánica Lagoon disclosed that the tumors were localized on a stretch of land northeast of the Lagoon. This area is bordered on the north by a small chain of foothills and lies approximately between latitude $18^{\circ} 0^{\prime}$ and $18^{\circ} 1^{\prime} \mathrm{N}$. and longitude $66^{\circ} 54^{\prime}$ and $66^{\circ} 55^{\prime}$ W. It is located southwest of the town of Yauco and north to northwest of Guánica on the southern coast of Puerto Rico. This land is part of a large multiple-purpose reclamation project involving the development of hydroelectric power, irrigation, drainage, water supply, and flood control, known as the Southwestern Puerto Rico Project, or more commonly as the Lajas Valley Development Project.

Figure 1 shows the location of piezometer batteries in the vicinity of the tumor area studied and table 1 gives information on the vertical direction of flow of the underground waters. This is an area of upward pressures. Probably the tumors result from this upward hydraulic gradient prevalent in the area. Evidently the pressure of the water is so high at certain periods of the year that it bursts through in some parts of the fields forcing up sus- 
pended clay, silt, and to a lesser extent, very fine sand particles. Field observations over a period of years suggest that these tumors are particularly active when the sugarcane growing on the upper lands bordering the af-

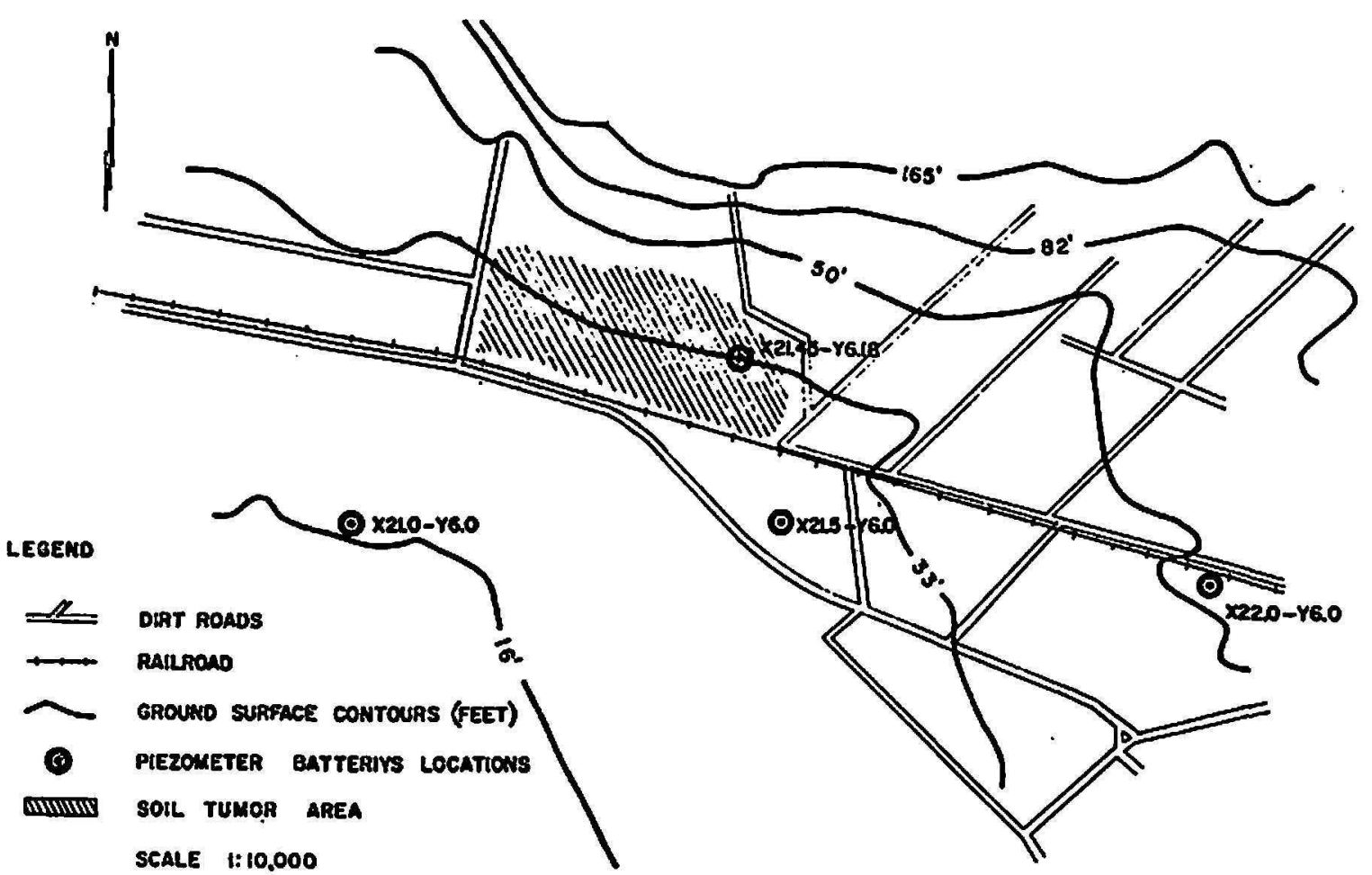

Fig. 1.-Area of tumor occurrence near the Guánica Lagoon in Lajas Valley, P.R., and location of piezomoters.

TABLE 1.-Piezometer data al tumor area, near Guanica Lagoon, Lajas Valley

\begin{tabular}{l|l|c|c}
\hline \multirow{2}{*}{ Piezometer location } & \multicolumn{2}{|c}{ Piezometer data, bydraulic head at depth indicated - } \\
\cline { 2 - 4 } & 28 in. & 14 in. & 7 in. \\
\hline & $I n$. & $I n$. & $I n$. \\
X21.0-Y6.0 & 22 & 10 & $(2)$ \\
X21.5-Y6.0 & 25 & 20 & $(2)$ \\
X21.45-Y6.18 & - & 33 & - \\
X22.0-Y6.0 & - & 48 & 48 \\
\hline
\end{tabular}

1 Datum plane, sea level.

2 Dry.

fected areas is irrigated. It seems that the applications of irrigation waters, probably in excess of the field capacity of the soil, may intensify the predominant upward hydraulic gradient of the underground water sufficiently to make it the causal factor in the bursting of the tumors. The same situation develops during the limited rainfall period. The water from the upper lands usually travels laterally in response to gravity, its downward move- 
ment into the subsoil being limited by the dominating upward gradients and the extremely slow hydraulic conductivity of the subsoil. The pressure is so high because of lack of outlets that bursting is inevitable at lower places.

The possibilities of relieving this upward hydraulic pressure are under study, as it constitutes a serious problem in some sections of the Valley (1). However, in no other areas in the Valley has the situation been so acute as to cause the formation of these oozing soil tumors. Figures 2 to 6 depict some aspects of the tumors.

\section{MECHANICAL COMPOSITION}

Table 2 gives data on the mechanical composition of the soil from the tumors and from the adjacent sites. They are both extremely high in their clay content at the upper 48 inches, being in all cases above 50-percent clay. The clay content increases slightly from the surface down to 48 inches. However, the variation in clay percentage is much more reduced in the tumors, while the range is wider in the adjacent soil. In general, the silt content is less than 22 percent and decreases with depth. The sand fraction is less than 30 percent in the upper 48 inches, but there is a marked increase to over 60 percent at the 48 - to 72 -inch depth. The increase in sand is mostly at the expense of the clay particles.

The mechanical makeup of both the soil from the tumors and from the adjacent sites indicates that most of the soil particles moving upward are in the clay-size range, and that the movement of clay is limited to the upper 48-inch layer. Evidently very little soil from the underlying 48- to 72-inch layers, or below, is moved upward through the action of the hydraulic pressure. The proportion of heavier fine sand at these depths in the tumor points to the movement of these particles, even if limited when compared to the fast-moving clay, probably of colloidal size, which can be easily suspended in the upward forcing waters. The natural mechanical separation of the soil particles from the tumors is probably similar to an elutriation process.

\section{ORGANIC-MATTER AND NITROGEN LEVELS}

Data on organic-matter and nitrogen contents of both the soil in the tumors and in the adjacent sites are given for each of four depths in table 3. In both cases the organic-matter levels decrease considerably from the topmost 8-inch layer to the lower 72-inch layer. The levels are, however, much higher in the soil from the site adjacent to the tumors than in the soils of the tumors proper, since the washout of the soil-water suspension carries some organic matter. The reduction in the level of organic matter 
काओ

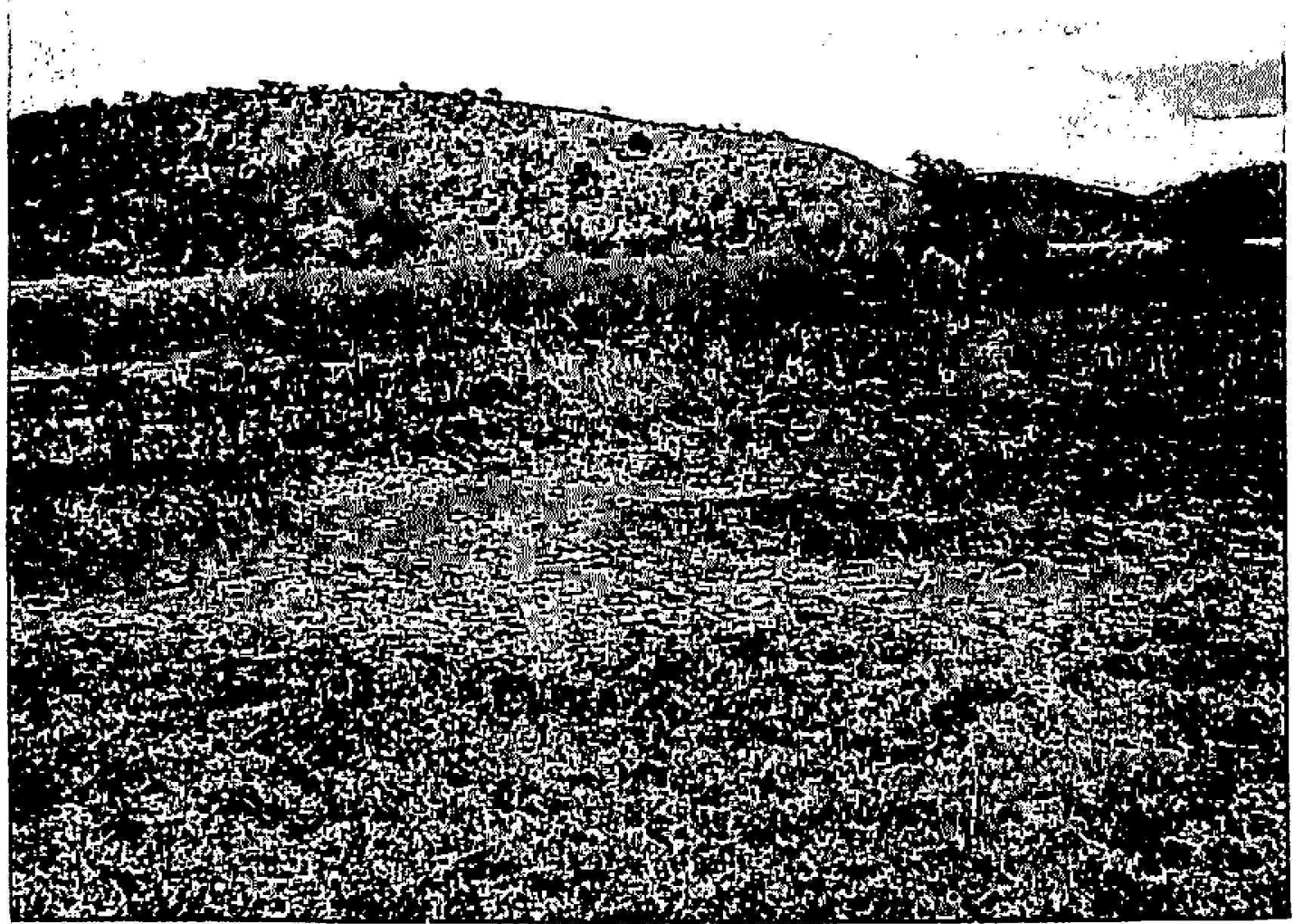

Frg. 2.-A recently formed bare, small, rounded tumor is shown at the center. A longer, rectangular, older one, fully covered with vegetation, may be observed to the right in the near background.

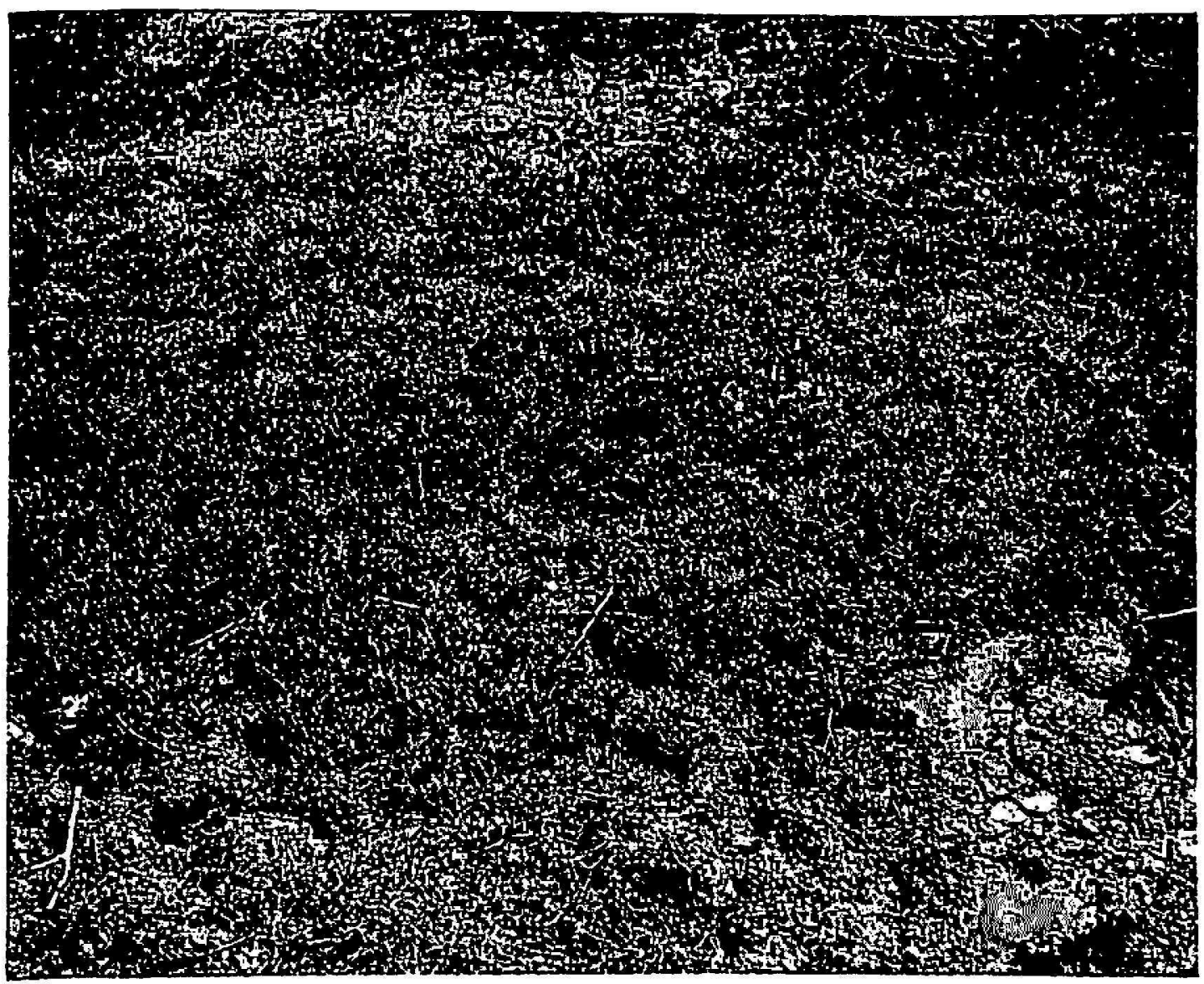

FIr. 3.-Closeup of the thick, fleshy, halophytic vegetation covering a small tumor. 
is sharp from the upper 8-inch layer to the lower layers. In the 8- to 2t-inch layer of the tumors it is approximately one-third as high as in the topmost 8-inch layer. In the soil adjacent to the tumors it drops about 50 percent at the corresponding depths. Nitrogen follows more or less the same pattern as the organic-matter levels. The nitrogen content of the soil adjacent to the tumors is almost twice as high in the upper 24 inches as that of the

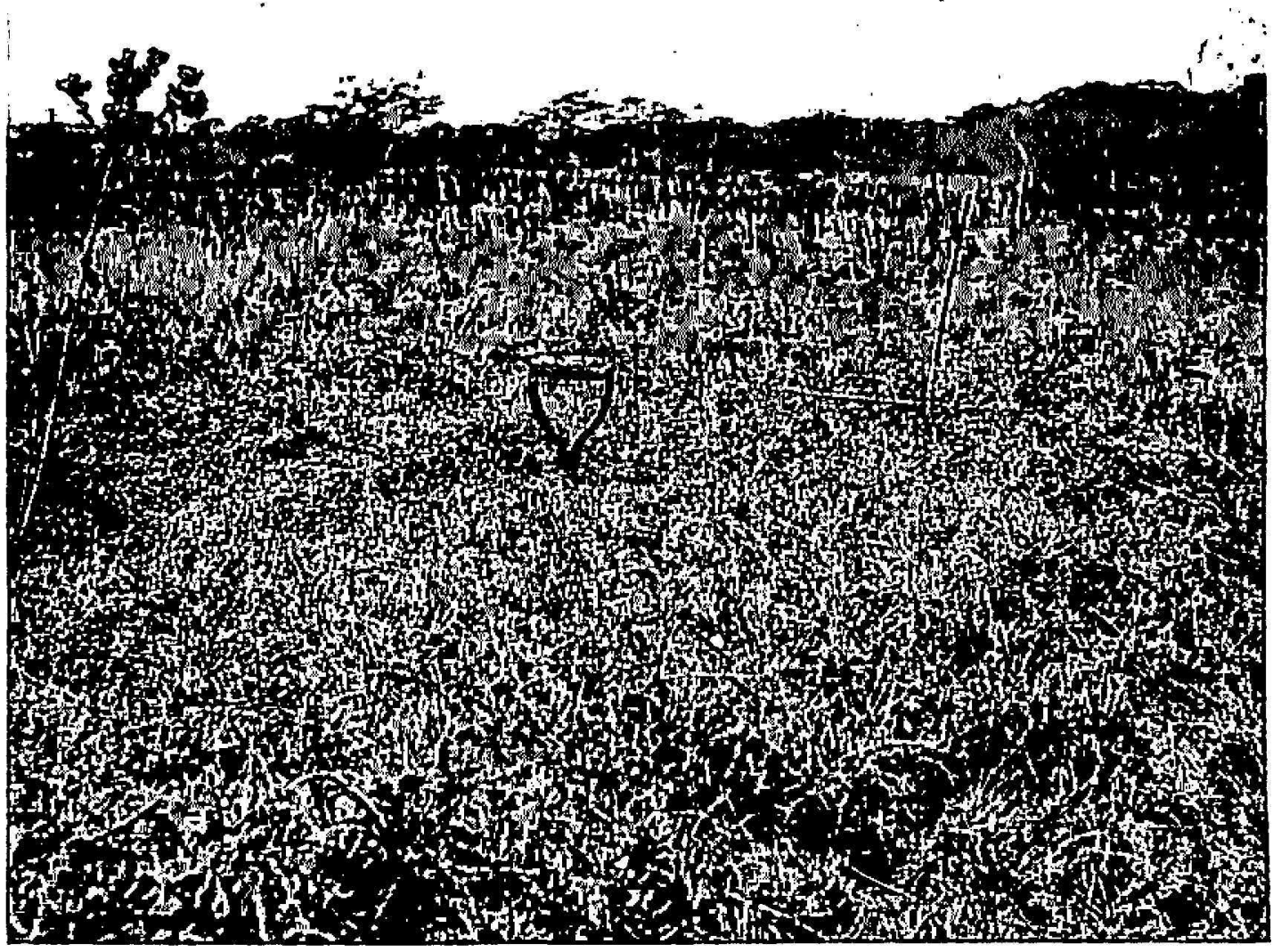

Fig. 4.-A spade can easily be shoved through the soft, aqueous, calcareous material of the tumors.

soil from the tumors. Below that depth there are practically no differences in the nitrogen level.

The growth of halophytic plants on the tumors seems to be rather rapid and luxuriant, and probably accounts, in large measure, for the rapid stabilization of the soil mounds and the quick accumulation of organic matter in the topsoil. Field observations indicated that halophytic, thick, fleshy plants took over shortly after the eruption of the tumors, covering them entirely. The succession of plants follows the normal trend and in older tumors even desertic trees and shrubs develop, probably as a climax vegetation. 


\section{CATION-EXCHANGE PIROPERTIES}

The total cation-exchange capacity of these soils is moderately high, with a mean difference of 5 to 6 m.e. per $100 \mathrm{gm}$. of dry soil, favoring the

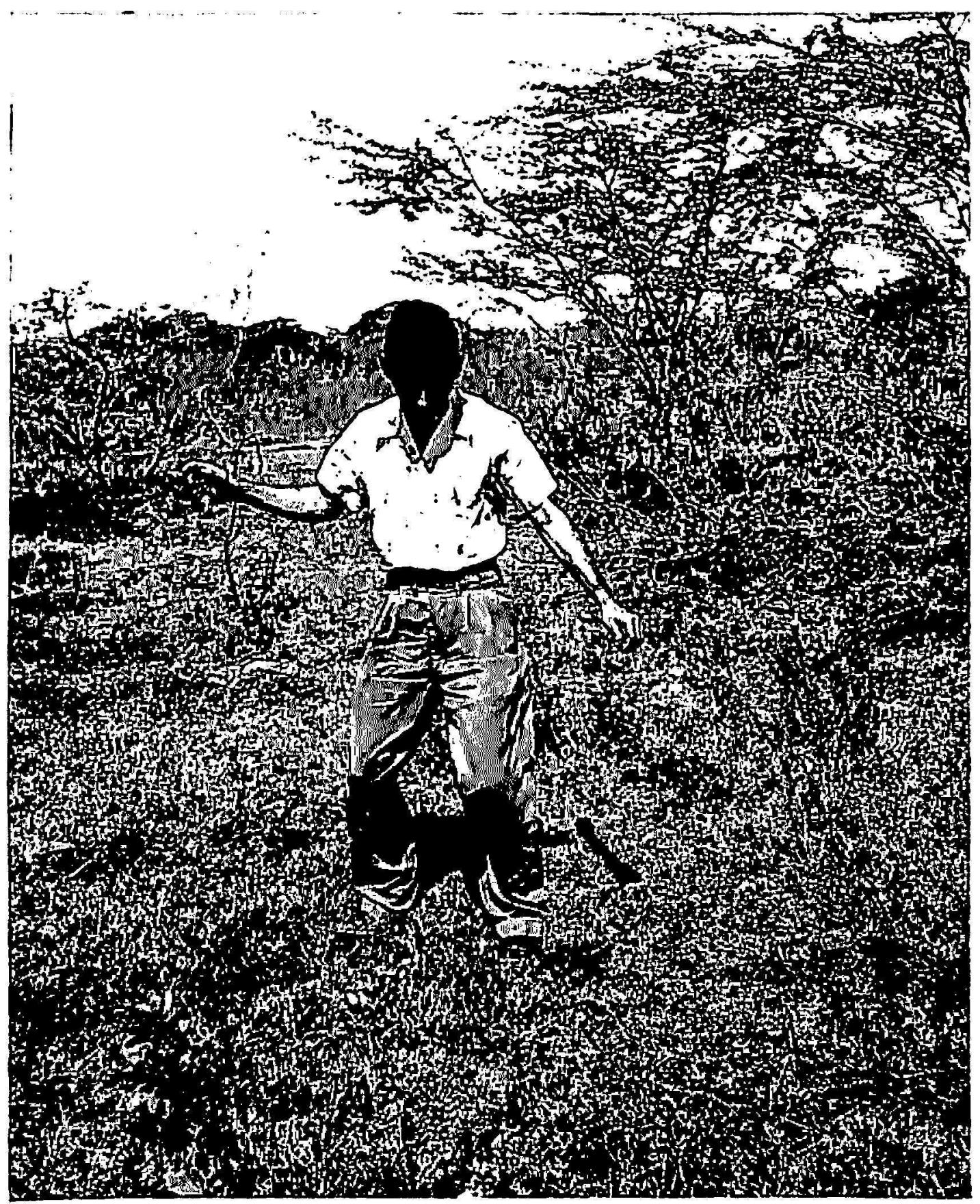

Frg. 5.-The soil under the thin, dry capping layer of the tumors is soft and easily displaced. In many instances the deep, soft soil of the tumors imperils both cattle and human beings.

soil from the tumors (table 4). This difference, marked throughout all layers, cannot be explained on a basis of differences in clay content. The differences in organic-matter levels offer no explanation either. The explanation 


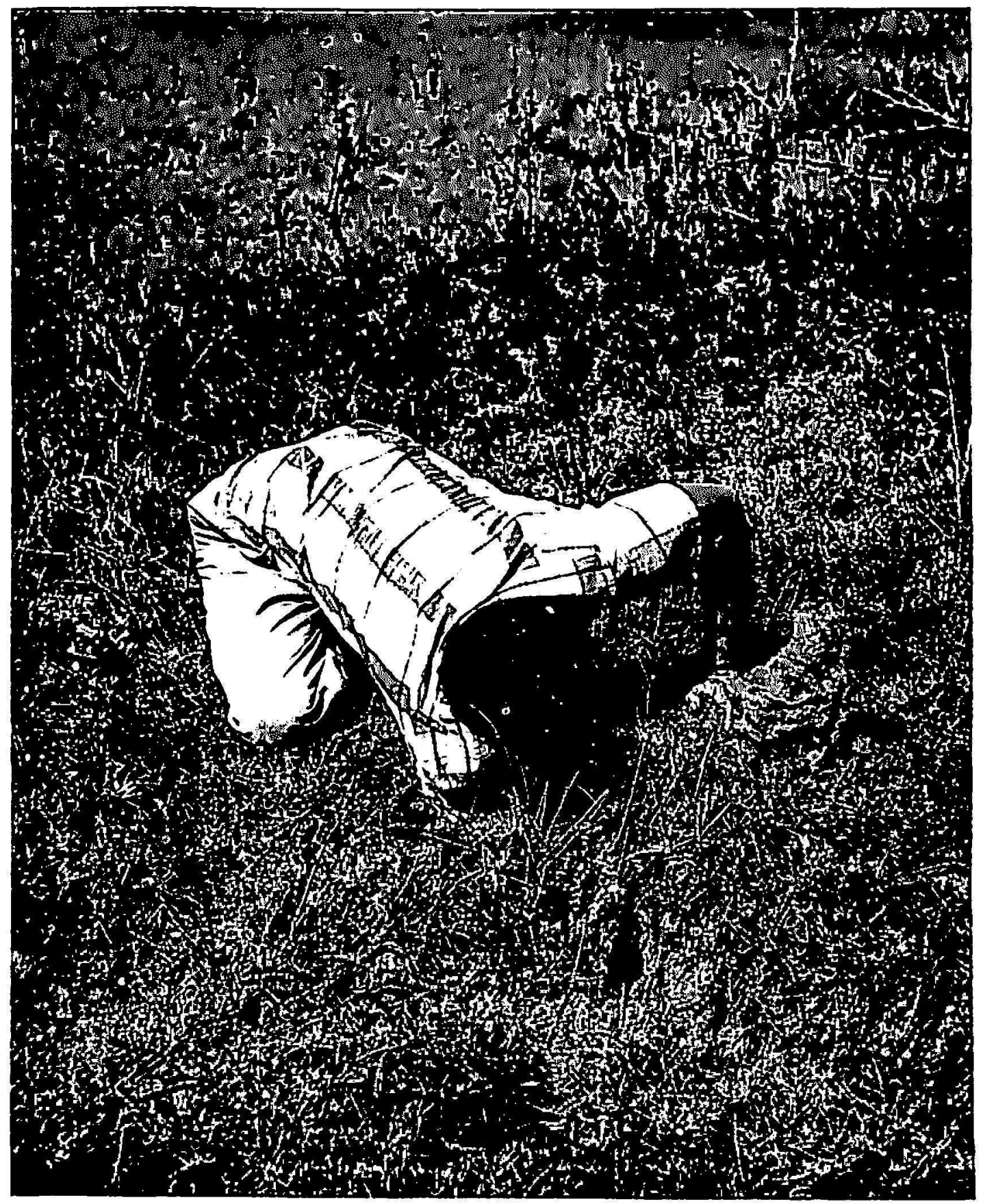

FIG. 6.-Large, deep cracks separate tumors from the adjacent soil. The soft, pliable, clayey material at the right was drawn beneath the dry soil capping the tumors.

must be sought in a study of the weathering cycle and the development of the clay minerals. In both cases the clay minerals are obviously of the 2:1 expanding-lattice type (2), montmorillonite predominating.

The predominance of sodium in the soil-exchange complex is a striking feature both in the soil from the tumors and from the adjacent sites. In 
some cases nearly all the exchangeable cations are apparently sodium, with but a small proportion of calcium, magnesium, and potassium. There is slightly more exchangeable $\mathrm{Ca}+\mathrm{Mg}$ and potassium in the upper 48 inches of the soils adjacent to the tumors, and slightly less at the 48- to 72-inch depth.

TABLE 2.-Mechanical composition of soils from different depths in the tumors and from adjacent siles, near Guanica Lagoon, Lajas Valley

\begin{tabular}{l|c|c|c|c}
\hline \multicolumn{1}{c|}{ Source of soil } & Depth & Sand & Silt & Clay \\
\cline { 2 - 4 } From tumors & Inches & Percent & Percent & Percent \\
& $0-8$ & 26 & 18 & 56 \\
& $8-24$ & 26 & 14 & 60 \\
From adjacent sites & $24-48$ & 24 & 14 & 62 \\
& $48-72$ & 60 & 12 & 28 \\
& $0-8$ & 28 & 22 & 50 \\
& $8-24$ & 28 & 16 & 56 \\
& $24-48$ & 30 & 6 & 64 \\
\hline
\end{tabular}

TABLE 3.-Organic-malter and nitrogen levels of soils from different depths in the tumors and from adjacent siles, near Guänica Lagoon, Lajas Valley

\begin{tabular}{l|c|c|c}
\hline \multicolumn{1}{c|}{ Source of soil } & Depth & Organic matter & Nitrogen \\
\cline { 2 - 4 } From tumors & Inches & Percent & Percent \\
& $0-8$ & 2.12 & 0.11 \\
& $8-24$ & .86 & .04 \\
From adjacent sites & $24-48$ & .63 & .04 \\
& $48-72$ & .35 & .02 \\
& $0-8$ & 3.44 & .21 \\
& $8-24$ & 1.63 & .10 \\
& $24-48$ & .77 & .05 \\
\hline
\end{tabular}

\section{CONDUCTIVITY, PH, AND SOLUBLE CATIONS}

As shown in table 5 , all the samples obtained are alkaline, all $\mathrm{pH}$ values being above 9.0 , with some even approaching $\mathrm{pH} 10$. The extremely high exchangeable-sodium percentage accounts for the alkalinity. Conductivity values are rather high, indicating a high salt level, but they are higher in the soils adjacent to the tumors than in the tumors themselves. Thus, the high sodium content, combined with the relatively low total salts in the tumors, probably accounts for more dispersion of the soil particles. Accord- 
TABLE 4.-Calion-exchange capacily and exchangeable cations in soils from the tumors and from adjacent siles, near Guánica Lagoon, Lajas Valley

\begin{tabular}{|c|c|c|c|c|c|}
\hline \multirow{2}{*}{ Source of soil } & \multirow{2}{*}{ Depth } & \multirow{2}{*}{$\begin{array}{l}\text { Cation- } \\
\text { exchange } \\
\text { capacity }\end{array}$} & \multicolumn{3}{|c|}{ Exchangeable cations of - } \\
\hline & & & $\mathrm{Na}$ & $\mathrm{Ca}+\mathrm{Mg}_{\mathrm{g}}$ & $\mathbf{K}$ \\
\hline & Inches & $3 f . e . / 100 \mathrm{gm}$. & M.e. $/ 100 \mathrm{gm}$. & 11.e./100 gm. & $M . e . / 100 \mathrm{gm}$. \\
\hline \multirow[t]{4}{*}{ From tumors } & $0-8$ & 38.1 & 26.96 & 9.65 & 1.49 \\
\hline & $8-24$ & 40.5 & 28.44 & 10.68 & 1.38 \\
\hline & $24-48$ & 40.4 & 28.80 & 10.42 & 1.18 \\
\hline & $48-72$ & 35.8 & 27.83 & 7.46 & .51 \\
\hline \multirow[t]{4}{*}{ From adjacent sites } & $0-8$ & 29.6 & 11.35 & 15.20 & 3.05 \\
\hline & $8-24$ & 24.5 & 16.29 & 15.88 & 2.33 \\
\hline & $24-48$ & 37.8 & 23.20 & 12.96 & 1.64 \\
\hline & $48-72$ & 27.1 & 20.13 & 6.61 & .36 \\
\hline
\end{tabular}

TABLE 5.-Mean conductivily of saluration extracts, $p H$, and soluble cations from the tumors and from the adjacent siles, near Guanica Lagoon, Lajas Valley

\begin{tabular}{l|c|c|c|c|c|c}
\hline \multicolumn{1}{c|}{ Source of soil } & Depth & Conductivity & $\mathrm{pH}$ & $\begin{array}{c}\text { Soluble Ca }+ \\
\text { Mg in satura- } \\
\text { tion extracts }\end{array}$ & $\begin{array}{c}\text { Soluble Na in } \\
\text { saturation } \\
\text { extracts }\end{array}$ \\
\hline \multirow{3}{*}{ From tumors } & Inches & M/mhros/cm. & & M.e./liter & Af.c./liter \\
& $0-8$ & 4.33 & 9.2 & 1.72 & 41.58 \\
& $8-24$ & 2.70 & 9.1 & 1.07 & 25.93 \\
& $24-48$ & 2.33 & 9.3 & .63 & 22.67 \\
& $48-72$ & 1.97 & 9.46 & .39 & 18.31 \\
& $0-8$ & 12.80 & 9.56 & 4.53 & 124.5 \\
& $8-24$ & 9.86 & 9.36 & 3.04 & 95.56 \\
& $24-48$ & 6.40 & 9.36 & 1.35 & 62.60 \\
& $48-72$ & 3.70 & 9.60 & 1.25 & 35.75 \\
\hline
\end{tabular}

'TABLE 6.-Saturation percenlage and waler relained at pF's 2.7 and 4.2 of soils from the tumors and from adjacent sites, near Guanica Lagoon, Lajas Valley

\begin{tabular}{l|c|c|c|c}
\hline \multirow{2}{*}{ Source of soil } & Depth & Saturation & \multicolumn{2}{|c}{ Water retained at $\mathrm{pF}$} \\
\cline { 2 - 4 } From tumors & & & 2.7 & 4.2 \\
\cline { 2 - 4 } & Inclies & Percent & Percent & Percent \\
& $0-8$ & 161.6 & 50 & 24 \\
& $8-24$ & 190.6 & 55 & 25 \\
& $24-48$ & 182.1 & 54 & 20 \\
& $48-72$ & 150.6 & 55 & 21 \\
& $0-8$ & 89.0 & 33 & 13 \\
& $8-24$ & 164.5 & 69 & 25 \\
& $24-48$ & 189.0 & 90 & 27 \\
& $48-72$ & 142.1 & 59 & 23 \\
\hline
\end{tabular}


ing to these data the soils from the tumors are, in general terms, nonsalinealkaline while those from the adjacent sites are saline-alkaline. Apparently, in the clay-water suspension oozing from the ruptured mounds or tumors some of the soluble salts are in some way leached out of the soil, thus reducing their total salt content and resulting in nonsaline-alkaline, but highly dispersed soils. The individual particles of such soils, especially those of colloidal size, can be moved easily and quickly when water is passed through the soil system under pressure.

\section{MOISTURE RELATIONS}

Table 6 presents data on saturation percentages and on water retention at $\mathrm{pF} 2.7$ and $\mathrm{pF}$ 4.2. In general, the saturation-percentage values, i.e., the moisture content of a saturated soil paste, are very high, surpassing 100 percent in most cases in soils from both sources at all sites studied. The trend is toward increased saturation percentages with depth down to 48 inches. This can be explained on basis of the increasing clay percentage of these soils down to that depth. In this same fashion the reduction at the 48- to 72-inch depth is marked, because of the significant reduction in clay content. Water retention when tensions in the vicinity of $\mathrm{pF}^{\prime} \mathrm{s} 2.7$ and 4.2 develop, is relatively high in both cases, following the same trend as saturation percentages. The high moisture content at $\mathrm{pF} 2.7$ indicates that most of the pores of these soils are definitely in the range of micropores with probably a small percentage of macropores. This is in line with the high clay percentages of the 2:1 expanding lattice clay types.

\section{SUMMARY}

The appearance of tumors or soil mounds oozing soil-water suspensions was observed during the course of a recent soil survey of Lajas Valley. The area affected lies northeast of the Guánica Lagoon and is generally covered by halophytic vegetation. Piezometer batteries installed in the area indicated a rather high upward pressure gradient throughout. This pressure is so high during rainfall, or when the sugarcane growing at the adjoining upper lands is irrigated, that water bursts through the soil, carrying along large quantities of soil particles in suspension.

Studies of the mechanical composition of the soils from the tumors and from adjacent sites indicate that the majority of the moving particles are In the clay-size range, although some silt and even very fine sand are forced upward from lower depths. Most of the movement is limited, however, to the upper 48 inches. The organic-matter and nitrogen levels are higher in the soils adjacent to the tumors than in the tumors themselves, but in both there is a sharp reduction below the 24-inch depth. The cation-exchange capacities of soils from both sites are rather high, with a predominance of 
exchangeable sodium in the complex, and but little calcium, magnesium, and potassium. The high exchangeable-sodium percentage, together with the lower salt content of the tumors, as indicated by conductivity of soil extracts, accounts for the highly dispersed nature of the soil.

The saturation percentages are extremely high, over 100 percent in most cases. They can be explained on basis of the extremely high clay percentages of the 2:1 expanding-lattice clay mineral types present.

\section{RESUMEN}

Durante un reconocimiento de los suelos hecho recientemente en el Valle de Lajas, se observaron tumores o promontorios de los cuales mana una suspensión de suelo en agua. El área en cuestión está ubicada al noroeste de la laguna Guánica y en general se halla cubierta de una vegetación halofítica. Las baterías de pizómetros localizadas en el área indican una alta presión ascendente en toda esta área. Durante épocas de lluvia o cuando se está regando la caña en la vecindad del área afectada, la presión es tan fuerte que el agua asciende a través del suelo trayendo gran cantidad del mismo en suspensión.

Los estudios sobre la composición mecánica del suelo de los tumores o promontorios y del suelo de sitios cercanos a los promontorios indican que la mayoría de las partículas en movimiento consiste de arcilla, con cantidades menores de limo y arena muy fina. Sin embargo, este movimiento está limitado, en su mayor grado, a las 48 pulgadas superficiales.

Los níveles de materia orgánica y nitrógeno son más altos en el suelo de los sitios cercanos a los tumores que en el de los tumores mismos, pero en ambos casos hay una marcada reducción bajo las primeras 24 pulgadas de profundidad.

La capacidad para el intercambio de cationes de los suelos de ambos sitios es moderadamente alta y predomina el sodio intercambiable con poco calcio, magnesio y potasio. El alto porcentaje de sodio intercambiable, conjuntamente con el bajo contenido de sales totales del suelo de los tumores, según lo indica la conductividad de los extractos del suelo, explican el alto grado de dispersión en que naturalmente se encuentra este suelo.

Los porcentajes de saturación de humedad de estos suelos son extremadamente altos y en muchos casos pasan del cien por ciento. Esto se debe a su alto contenido de arcilla con estructuras cristalinas del tipo 2:1, la cual se expande y contrae.

\section{LITERATURE CITED}

1. Israelsen, O. W., Drainage and Reclamation Problems in Lajas Valley, Puerto Rico, Univ. P.R., Agr. Exp. Sta., 48 mimeographed pages, July 1954.

2. Jeffries, C. D., Bonnet, J. A., and Abruna, F., The constituent minerals of some soils of Puerto Rico, J. Agr. Univ. P.R. 37 (2) 114-39, 1953. 
3. Richards, L. A., ed., Diagnosis and Improvement of Saline and Alkali Soils, Agr. Handbook No. 60, U. S. Salinity Lab., 1954.

4. Roberts, R. C., Soil survey of Puerto Rico, USDA in cooperation with P.R. Univ. Agr. Exp. Sta., Series 1936, No. 8, 1942.

5. Peech, M., Determination of exchangeable bases in soils, Ind. Eng. Chem. Anal. 13 (6) $436-41,1941$. 